\title{
The emerging research field of extracellular RNA: an editorial preface
}

\author{
Ke Zen and Chen-Yu Zhang ${ }^{*}$
}

It is our very great pleasure to announce the launch of ExRNA, a peer-reviewed, open-access journal aiming to develop a platform for innovative research in the field of extracellular RNA.

Because RNA is thought to be unstable in the extracellular environment, the presence of extracellular RNA and the significance of extracellular RNA began to emerge only recently. Although there were scattered reports that the secreted RNA could be translated into proteins by the recipient cells $[1,2]$, the role of secreted RNA as a mechanism of communication among cells was initially underappreciated. This situation changed with the discovery of highly stable extracellular microRNA (miRNA), a class of 22-nt non-coding RNA, in animal and human plasma and serum [3, 4].

In the past decade, we have witnessed astonishing research progress in the new and exciting field of discovery focused on extracellular RNA. Numerous studies have demonstrated that extracellular miRNAs can serve as non-invasive biomarkers for various diseases including cancer [5, 6]. Cell-secreted extracellular vesicles, such as exosomes and microvesicles, have been recognized as ideal carriers for functional extracellular RNAs [7, 8]. Additionally, our understanding has been advanced by the classification of non-coding RNAs into various functional categories including small interfering RNAs (siRNAs), Piwi-interacting RNAs (piRNAs), long non-coding RNAs (lncRNAs) and circular RNAs (circRNAs). Although there is yet much to be discovered regarding the function and biogenesis of these non-coding RNAs, accumulating evidence suggests that these RNAs can be broadly transferred among different cell types both within a host $[9,10]$ and across species [11-15]. Moreover, the functional significance of the transfer of RNAs in regulating the cellular function of the recipient cells has been vigorously investigated [16-18]. Understanding the roles of these extracellular RNAs in contributing to the progression of

\footnotetext{
* Correspondence: cyzhang@nju.edu.cn

NJU Advanced Institute for Life Sciences, Jiangsu Engineering Research Center for MicroRNA Biology and Biotechnology, School of Life Sciences, Nanjing University, 163 Xianlin Avenue, Nanjing 210023, China
}

disease offers new opportunities for efficacious treatments [19].

Heretofore, investigations in this new area of inquiry into the identity, function, and significance of extracellular RNAs have been published across a broad spectrum of journals. The purpose of launching ExRNA is to meet the urgent demand for a journal that can serve as a repository covering the diverse field of extracellular RNA research. The journal will cover all areas of experimental laboratory and clinical research relevant to various types of extracellular RNAs. Our objective is to expedite the rapid exchange of important new information in as accessible a manner as possible. The primary criteria for acceptance will be originality and merit.

Our Editorial Board will work tirelessly to bring this journal to fruition by inviting publications on selected topics, by reviewing manuscripts, and by offering valuable advice. ExRNA is an ideal platform for international scientists to disseminate their discoveries to a wide audience and to discuss their science and topical issues. We call upon our colleagues worldwide to join us in support of ExRNA and to help build it into an objective, advanced, open and successful journal.

\section{Acknowledgements}

Not applicable.

\section{Funding}

Not applicable.

\section{Availability of data and materials Not applicable.}

\section{Authors' contributions}

KZ and C-YZ wrote the manuscript. Both authors read and approved the final manuscript.

\section{Ethics approval and consent to participate Not applicable.}

\section{Consent for publication \\ Not applicable.}

\section{Competing interests}

The authors declare that they have no competing interests. 


\section{Publisher's Note}

Springer Nature remains neutral with regard to jurisdictional claims in published maps and institutional affiliations.

Received: 7 January 2019 Accepted: 7 January 2019

Published online: 14 February 2019

\section{References}

1. Valadi H, Ekstrom K, Bossios A, Sjostrand M, Lee JJ, Lotvall JO. Exosomemediated transfer of mRNAs and microRNAs is a novel mechanism of genetic exchange between cells. Nat Cell Biol. 2007;9(6):654-9.

2. Skog J, Wuerdinger T, van Rijn S, Meijer DH, Gainche L, Sena-Esteves M, Curry WT Jr, Carter BS, Krichevsky AM, Breakefield XO. Glioblastoma microvesicles transport RNA and proteins that promote tumour growth and provide diagnostic biomarkers. Nat Cell Biol. 2008;10(12):1470-U1209.

3. Mitchell PS, Parkin RK, Kroh EM, Fritz BR, Wyman SK, Pogosova-Agadjanyan EL, Peterson A, Noteboom J, O'Briant KC, Allen A, et al. Circulating microRNAs as stable blood-based markers for cancer detection. Proc Natl Acad Sci U S A. 2008;105(30):10513-8.

4. Chen X, Ba Y, Ma L, Cai X, Yin Y, Wang K, Guo J, Zhang Y, Chen J, Guo X, et al. Characterization of microRNAs in serum: a novel class of biomarkers for diagnosis of cancer and other diseases. Cell Res. 2008;18(10):997-1006.

5. Berindan-Neagoe I, Monroig Pdel C, Pasculli B, Calin GA. MicroRNAome genome: a treasure for cancer diagnosis and therapy. CA Cancer J Clin. 2014;64(5):311-36

6. Zen K, Zhang CY. Circulating microRNAs: a novel class of biomarkers to diagnose and monitor human cancers. Med Res Rev. 2012;32(2):326-48.

7. Zhang Y, Liu D, Chen X, Li J, Li L, Bian Z, Sun F, Lu J, Yin Y, Cai X, et al. Secreted monocytic miR-150 enhances targeted endothelial cell migration. Mol Cell. 2010;39(1):133-44.

8. Kosaka N, Iguchi H, Yoshioka Y, Takeshita F, Matsuki Y, Ochiya T. Secretory mechanisms and intercellular transfer of MicroRNAs in living cells. J Biol Chem. 2010:285(23):17442-52.

9. El Andaloussi S, Maeger I, Breakefield XO, Wood MJA. Extracellular vesicles: biology and emerging therapeutic opportunities. Nat Rev Drug Discov. 2013;12(5):348-58

10. Chen $\mathrm{X}$, Liang H, Zhang J, Zen K, Zhang C-Y. Horizontal transfer of microRNAs: molecular mechanisms and clinical applications. Protein Cell. 2012;3(1):28-37.

11. Weiberg A, Wang M, Lin FM, Zhao H, Zhang Z, Kaloshian I, Huang HD, Jin H. Fungal small RNAs suppress plant immunity by hijacking host RNA interference pathways. Science. 2013;342(6154):118-23.

12. Zhou Z, Li X, Liu J, Dong L, Chen Q, Liu J, Kong H, Zhang Q, Qi X, Hou D, et al. Honeysuckle-encoded atypical microRNA2911 directly targets influenza a viruses. Cell Res. 2015;25(1):39-49.

13. Weiberg $A$, Wang $M$, Bellinger $M$, Jin HL. Small RNAs: a new paradigm in plant-microbe interactions. Annu Rev Phytopathol. 2014;52:495-516.

14. Zhang L, Hou DX, Chen X, Li DH, Zhu LY, Zhang YJ, Li J, Bian Z, Liang XY, Cai $X$, et al. Exogenous plant MIR168a specifically targets mammalian LDLRAP1: evidence of cross-kingdom regulation by microRNA. Cell Res. 2012;22(1):107-26.

15. Yang J, Hirschi KD, Farmer LM. Dietary RNAs: new stories regarding oral delivery. Nutrients. 2015;7(5):3184-99.

16. Zhou WY, Fong MY, Min YF, Somlo G, Liu L, Palomares MR, Yu Y, Chow A, O'Connor STF, Chin AR, et al. Cancer-secreted miR-105 destroys vascular endothelial barriers to promote metastasis. Cancer Cell. 2014;25(4):501-15

17. Mittelbrunn M, Gutierrez-Vazquez C, Villarroya-Beltri C, Gonzalez S, SanchezCabo F, Angel Gonzalez M, Bernad A, Sanchez-Madrid F. Unidirectional transfer of microRNA-loaded exosomes from $T$ cells to antigen-presenting cells. Nat Commun. 2011;2:282.

18. Hergenreider E, Heydt S, Treguer K, Boettger T, Horrevoets AJG, Zeiher AM, Scheffer MP, Frangakis AS, Yin X, Mayr M, et al. Atheroprotective communication between endothelial cells and smooth muscle cells through miRNAs. Nat Cell Biol. 2012;14(3):249.

19. Yin Y, Cai X, Chen X, Liang H, Zhang Y, Li J, Wang Z, Chen X, Zhang W, Yokoyama $S$, et al. Tumor-secreted miR-214 induces regulatory $T$ cells: a major link between immune evasion and tumor growth. Cell Res. 2014; 24(10):1164-80.

Ready to submit your research? Choose BMC and benefit from:

- fast, convenient online submission

- thorough peer review by experienced researchers in your field

- rapid publication on acceptance

- support for research data, including large and complex data types

- gold Open Access which fosters wider collaboration and increased citations

- maximum visibility for your research: over $100 \mathrm{M}$ website views per year

At BMC, research is always in progress.

Learn more biomedcentral.com/submissions 